\title{
Structural analysis and corrosion studies on an ISO 5832-9 biomedical alloy with $\mathrm{TiO}_{2}$ sol-gel layers
}

\author{
B. Burnat · G. Dercz • T. Blaszczyk
}

Received: 9 September 2013 / Accepted: 11 November 2013/Published online: 23 November 2013

(C) The Author(s) 2013. This article is published with open access at Springerlink.com

\begin{abstract}
The aim of this study was to demonstrate the relationship between the structural and corrosion properties of an ISO 5832-9 biomedical alloy modified with titanium dioxide $\left(\mathrm{TiO}_{2}\right)$ layers. These layers were obtained via the sol-gel method by acid-catalyzed hydrolysis of titanium isopropoxide in isopropanol solution. To obtain $\mathrm{TiO}_{2}$ layers with different structural properties, the coated samples were annealed at temperatures of 200, 300, 400, 450, 500, 600 and $800{ }^{\circ} \mathrm{C}$ for $2 \mathrm{~h}$. For all the prepared samples, accelerated corrosion measurements were performed in Tyrode's physiological solution using electrochemical methods. The most important corrosion parameters were determined: corrosion potential, polarization resistance, corrosion rate, breakdown and repassivation potentials. Corrosion damage was analyzed using scanning electron microscopy. Structural analysis was carried out for selected $\mathrm{TiO}_{2}$ coatings annealed at $200,400,600$ and $800{ }^{\circ} \mathrm{C}$. In addition, the morphology, chemical composition, crystallinity, thickness and density of the deposited $\mathrm{TiO}_{2}$ layers were determined using suitable electron and X-ray measurement methods. It was shown that the structure and character of interactions between substrate and deposited $\mathrm{TiO}_{2}$ layers depended on annealing temperature. All the obtained $\mathrm{TiO}_{2}$ coatings exhibit anticorrosion properties, but these properties are related to the crystalline structure and character of substrate-layer interaction. From the point of view of corrosion, the best $\mathrm{TiO}_{2}$ sol-gel coatings for
\end{abstract}

B. Burnat $(\bowtie) \cdot$ T. Blaszczyk

Department of Inorganic and Analytical Chemistry, Faculty of Chemistry, University of Lodz, Tamka 12, 91-403 Lodz, Poland e-mail: burnat@chemia.uni.lodz.pl

G. Dercz

Institute of Materials Science, University of Silesia,

75 Pulku Piechoty 1A, 41-500 Chorzow, Poland stainless steel intended for biomedical applications seem to be those obtained at $400{ }^{\circ} \mathrm{C}$.

\section{Introduction}

Biomaterials belong to the group of modern materials which are used for the repair and reconstruction of human body. Some of the application examples of those materials are prostheses and implants that are used in nearly every medical discipline. A very important group of biomaterials are metallic materials-pure metals and alloys. FeCrNi alloys are the most often used biomaterials for bone implants and surgical instruments; for example, the popular AISI 316L (ISO 5832-1) stainless steel and the comparable Rex 734 (ISO 5832-9) alloy. The good mechanical properties and biocompatibility of both the mentioned $\mathrm{FeCrNi}$ alloys make them very attractive for biomedical applications [1]. However, it is known that steel implants corrode in the body. They release iron, chromium and nickel ions, which can cause severe allergic reactions [2]. Rex 734 is quite a new alloy, which is more corrosion resistant than AISI 316L steel [3]. The chemical composition of both the mentioned alloys according to ISO standards is presented in Table 1 [4].

Various surface modification techniques have been developed to improve the properties of metallic biomaterials, especially their corrosion resistance and biocompatibility. One of the most effective methods is to cover the metal surface with a ceramic coating, e.g., nitrides, carbides and transition metal oxides. Coatings on metal surfaces can be created in different ways: the PVD [5] and CVD [6] methods from gaseous phase or the sol-gel method [7] and electrodeposition [8] from the liquid phase. The sol-gel method is often used for deposition of oxide 


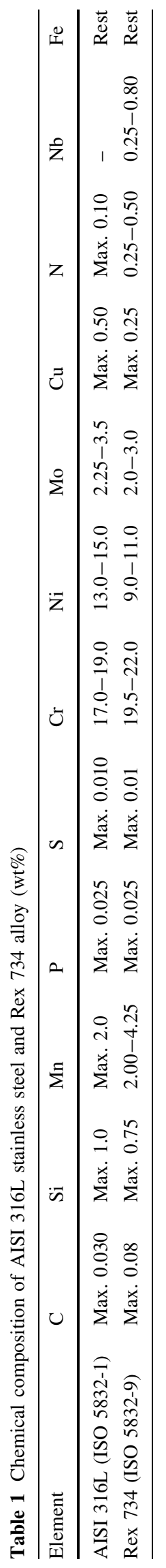

films such as $\mathrm{TiO}_{2}, \mathrm{SiO}_{2}$ and $\mathrm{Al}_{2} \mathrm{O}_{3}$ [9-13]. They are used as single-layer or multi-layer coatings. Sol-gel coatings show excellent chemical stability, oxidation control and provide enhanced corrosion resistance for metal substrates [13]. This deposition technique offers various advantages, including the precise control of the chemical composition, thickness, and microstructure of the coating and the possibility to prepare homogeneous films [14]. The sol-gel method enables the production of amorphous or crystalline layers depending on the applied temperature [10]. In comparison with the other coating methods, the sol-gel process requires less equipment and so is less expensive.

Titanium dioxide $\left(\mathrm{TiO}_{2}\right.$, titania) is an important ceramic material with versatile applications due to its self-cleaning character, biocompatibility and corrosion resistance. Some positive properties of titanium dioxide depend on its phase structure. $\mathrm{TiO}_{2}$ exists in three different crystal phases: rutile, anatase and brookite. Rutile is a thermodynamic stable state, while the other two phases are metastable states [15]. Anatase is the low-temperature form of $\mathrm{TiO}_{2}\left(300-550{ }^{\circ} \mathrm{C}\right)$ and it transforms into rutile during heating (ca. $1100{ }^{\circ} \mathrm{C}$ ) [16]. Other authors report that the transformation from anatase to rutile proceeds in the temperature range of $500-750{ }^{\circ} \mathrm{C}$ and both $\mathrm{TiO}_{2}$ forms exist in films. Above the temperature of $750{ }^{\circ} \mathrm{C}, \mathrm{TiO}_{2}$ exists as pure rutile [10].

The literature describes the different properties of $\mathrm{TiO}_{2}$ coatings, deposited on various substrates including silicon wafers, glasses and metallic materials (e.g. steels). Most of the publications about $\mathrm{TiO}_{2}$ films describe their phase structure, thickness, porosity and adherence to substrates. The influence of $\mathrm{TiO}_{2}$ coatings on the corrosion properties of stainless steel are also reported in the literature [17-23]. Several authors stated that $\mathrm{TiO}_{2}$ films improved corrosion resistance by acting as a protective barrier on the steel surface [18-20, 23-25].

There are only a few reports describing the nature of the steel substrate- $\mathrm{TiO}_{2}$ film connection [26, 27]. Evans [26] wrote that the components of stainless steel (mainly $\mathrm{Fe}$ and/or Cr) diffuse into the titania film. Zhu et al. [27] reported that $\mathrm{Fe}$ diffuses from the steel substrate into the $\mathrm{TiO}_{2}$ film and reacts with $\mathrm{O}_{2}$ from the air. As a result, an interlayer of iron oxide forms during the annealing process. Zhu et al. [27] stated that $\mathrm{Fe}$ in the $\mathrm{TiO}_{2}$ layer and interlayer exists as a rhombohedral $\mathrm{Fe}_{2} \mathrm{O}_{3}$ species. The author asserts as well that the degree of diffusion is associated with increasing annealing temperature and time. Such diffusion has a deleterious effect on the photoactivity of the titania films obtained by CVD or sol-gel methods [26, 27]. Unfortunately, in the literature there is no information about the influence of the mentioned interlayers on the corrosion properties of steel coated by $\mathrm{TiO}_{2}$ sol-gel layers.

The objective of this study was to demonstrate the relationship between the structural and corrosion properties 
of an ISO 5832-9 biomedical alloy modified with $\mathrm{TiO}_{2}$ solgel layers. Different structural properties of $\mathrm{TiO}_{2}$ layers were obtained by applying a variety of annealing temperatures. The morphology, chemical composition, crystallinity, thickness and density of $\mathrm{TiO}_{2}$ layers were characterized by X-ray measurement methods. The interaction type and boundary structure of the substrate- $\mathrm{TiO}_{2}$ layer were determined on the basis of structural analysis results. The corrosion behavior of the examined alloy coated by $\mathrm{TiO}_{2}$ was determined in Tyrode's physiological solution using electrochemical methods. Several corrosion parameters were determined: corrosion potential, polarization resistance, corrosion rate $(\mathrm{CR})$, breakdown and repassivation potentials. Corrosion damage was analyzed using scanning electron microscopy.

\section{Experimental}

\subsection{Materials}

The biomedical alloy Rex 734 (MEDGAL, Białystok, Poland) was used as a metallic substrate. Its chemical composition is as follows (wt\%): $\mathrm{Cr}$ (20.79), $\mathrm{Ni}$ (9.81), Mo (2.22), Mn (4.07), Nb (0.32), N (0.40), Si (0.40), Cu (0.07), $\mathrm{C}(0.034), \mathrm{S}(\leq 0.002), \mathrm{P}(0.019), \mathrm{Al}+\mathrm{Co}+\mathrm{V}(0.19)$ and $\mathrm{Fe}$ (balance). Rex 734 alloy samples were discs with a diameter of $28 \mathrm{~mm}$ and height ca. $3 \mathrm{~mm}$. Sample surfaces were grinded on $\mathrm{SiC}$ abrasive paper, mechanically polished with $\mathrm{Al}_{2} \mathrm{O}_{3}$ suspension and cleaned in an ultrasonic bath. The last stage of the surface preparation procedure included etching of sample surfaces for a short time in a mixture of $2 \% \mathrm{HF}, 10 \% \mathrm{HNO}_{3}$ and $88 \% \mathrm{H}_{2} \mathrm{O}$. Next, the samples were cleaned in an ultrasonic bath again, rinsed with ethanol and dried with Ar (99.999 \%). Samples prepared in such a way were ready for $\mathrm{TiO}_{2}$ coating.

$\mathrm{TiO}_{2}$ layers were obtained from sol, in which titanium (IV) isopropoxide $\mathrm{Ti}\left[\mathrm{OCH}\left(\mathrm{CH}_{3}\right)_{2}\right]_{4}(97 \%$, Aldrich) was used as a precursor, isopropanol (99.7 \%, POCh) as a medium and $2 \mathrm{M} \mathrm{HCl}$ (POCh) as a catalyst. Such sol was used by Piwoński for synthesis of non-porous $\mathrm{TiO}_{2}$ layers [28].

All the chemical reagents used in the experiment were analytical grade and were applied without further purification.

\subsection{Synthesis of $\mathrm{TiO}_{2}$}

The preparation of $\mathrm{TiO}_{2}$ sol solution was started by mixing $0.00422 \mathrm{~mol}(1.2 \mathrm{~g})$ of titanium (IV) isopropoxide with $0.22 \mathrm{~mol}$ (13.2 g) of isopropanol. Next, $0.0011 \mathrm{~mol}$ $(0.04 \mathrm{~g})$ of hydrochloric acid was added dropwise to the solution and then the mixture was stirred vigorously for $45 \mathrm{~min}$ at room temperature. The resultant titanium precursor sol was homogenous and clear. It could be used for the preparation of $\mathrm{TiO}_{2}$ films on Rex 734 alloy samples.

The $\mathrm{TiO}_{2}$ layers were obtained by immersing the sample once into the sol using DCMono 75 (NIMA Technology). The immersion speed and withdrawal speed were $20 \mathrm{~mm} \mathrm{~min}^{-1}\left(0.33 \mathrm{~mm} \mathrm{~s}^{-1}\right)$ and the immersion time in bottom state in sol was $30 \mathrm{~s}$. Even during withdrawal of the already coated sample, the solvent evaporated and at the same time the alkoxide was hydrolyzed by the atmospheric water, forming titanium hydroxide and isopropanol according to reaction (1):

$\mathrm{Ti}\left[\mathrm{OCH}\left(\mathrm{CH}_{3}\right)_{2}\right]_{4}+4 \mathrm{H}_{2} \mathrm{O} \stackrel{\mathrm{H}^{+}}{\longrightarrow} \mathrm{Ti}(\mathrm{OH})_{4}+4\left(\mathrm{CH}_{3}\right)_{2} \mathrm{CHOH}$

During ongoing acid-catalyzed hydrolysis, polycondensation of the hydrolyzed particles occurred. $\mathrm{Ti}(\mathrm{OH})_{4}$ molecules formed $-\mathrm{Ti}-\mathrm{O}-\mathrm{Ti}-$ connections by elimination of water according to reaction (2):

$2 \mathrm{Ti}(\mathrm{OH})_{4} \rightarrow(\mathrm{OH})_{3} \mathrm{Ti}-\mathrm{O}-\mathrm{Ti}(\mathrm{OH})_{3}+\mathrm{H}_{2} \mathrm{O}$

A three-dimensional network of $-\mathrm{Ti}-\mathrm{O}-\mathrm{Ti}-$ connections formed, when reaction (2) was repeated. As a result, amorphous $\mathrm{TiO}_{2}$ particles were formed.

After the coating process, the samples were initially dried at $100{ }^{\circ} \mathrm{C}$ for $2 \mathrm{~h}$ in the air using a muffle furnace. During drying, most of the isopropanol and water evaporated and an agglomeration of the $\mathrm{TiO}_{2}$ particles was created in the film (i.e. gel formation). Next, the samples were divided into seven groups and each group was annealed at different temperatures: $200,300,400,450,500,600,800{ }^{\circ} \mathrm{C}$ for $2 \mathrm{~h}$. The rate of temperature increase was $10{ }^{\circ} \mathrm{C} \min ^{-1}$. Finally, the samples were cooled to room temperature in the furnace. The resultant $\mathrm{TiO}_{2}$ layers assumed different colors, depending on the annealing temperature. For example, after heating at 200 and $400{ }^{\circ} \mathrm{C}$ the layers were gold, after heat treatment at $600{ }^{\circ} \mathrm{C}$ they were blue, while at $800{ }^{\circ} \mathrm{C}$ they became grey. At all temperatures, the resultant $\mathrm{TiO}_{2}$ layers were homogeneous over their whole surface and were free of cracks.

\subsection{Characterization of $\mathrm{TiO}_{2}$ layers}

Structural analysis was carried out for selected $\mathrm{TiO}_{2}$ coatings annealed at $200,400,600$ and $800{ }^{\circ} \mathrm{C}$.

All X-ray diffraction experiments were carried out using a X-Pert Philips PW 3040/60 diffractometer, operated at $30 \mathrm{~mA}$ and $40 \mathrm{kV}$, equipped with a vertical goniometer and an Eulerian cradle. The length of radiation $\left(\lambda \mathrm{Cu}_{\mathrm{K} \alpha}\right)$ was $1.54178 \AA$.

The set-ups of the GIXD (Grazing Incident X-ray diffraction) and XRR (X-Ray reflectivity) optics are detailed in Table 2. 
Table 2 X-ray beam formation for asymmetrical and GIXD, XRR geometry

\begin{tabular}{llllllrr}
\hline Geometry & $\begin{array}{l}\text { Soller } \\
\text { slit }(\mathrm{rad})\end{array}$ & $\begin{array}{l}\text { Div. } \\
\text { slit }\left({ }^{\circ}\right)\end{array}$ & $\begin{array}{l}\text { Mask } \\
\text { width }(\mathrm{mm})\end{array}$ & $\begin{array}{l}\text { Anti-scatter } \\
\text { slit }\left(^{\circ}\right)\end{array}$ & $\begin{array}{l}\text { Rec. slit } \\
(\mathrm{mm})\end{array}$ & $\begin{array}{l}\text { Soller slit } \\
(\mathrm{rad})\end{array}$ & $\begin{array}{l}\text { Curved crystal } \\
\text { monochromator }\end{array}$ \\
\hline GIXD & 0.04 & $1 / 32$ & 5 & $1 / 32$ & 0.3 & 0.04 & PW3123/10 \\
XRR & 0.04 & $1 / 32$ & 5 & $1 / 32$ & 0.3 & 0.04 & PW3123/10 \\
\hline
\end{tabular}

Table 3 Chemical composition of Tyrode's solution

\begin{tabular}{lllllll}
\hline & $\mathrm{NaCl}$ & $\mathrm{KCl}$ & $\mathrm{CaCl}_{2}$ & $\mathrm{NaHCO}_{3}$ & $\mathrm{MgCl}_{2} \cdot 6 \mathrm{H}_{2} \mathrm{O}$ & $\mathrm{NaH}_{2} \mathrm{PO}_{4} \cdot \mathrm{H}_{2} \mathrm{O}$ \\
\hline$\left[\mathrm{g} \mathrm{dm}^{-3}\right]$ & 8.000 & 0.200 & 0.200 & 1.000 & 2.135 & 0.0575 \\
\hline
\end{tabular}

The GIXD diffraction patterns were registered in $2 \theta$ range from $10^{\circ}$ to $120^{\circ}$ and $0.05^{\circ}$ step for the incident angle $\alpha: 0.25 ; 0.50 ; 1.00 ; 2.50$ and 5.00 degrees, respectively. In order to maintain comparable intensities of the diffraction lines, the conditions for collecting patterns (step and counting time) were properly adjusted. GIXD uses small incident angles $(\alpha)$ for the incident X-ray beam, so that it is used to study surface layers as the beam penetration is limited. Distances are in the order of nanometers. The $\alpha$ angle of incidence is fixed, so that the degree of penetration by the X-rays into the sample remains constant throughout the measurement. At low $\alpha$-angles of incidence, the X-rays penetrate only the uppermost layers of a sample. At higher $\alpha$-angles of incidence, the X-rays penetrate more deeply into the sample $[29,30]$.

The reflectometric curves were collected in $2 \theta$ range from $0.15^{\circ}$ to $3^{\circ}$ and step $0.005^{\circ}$. An attenuator was used in order to reduce scattered intensity. XRR is based on measuring the scattering from the layer and the substrate that differ in their density. This method provides information about layer thickness and density [31, 32]. The parameters of the layer were found by fitting the experimental reflectometric curves to the theoretical curves [33].

The SEM (JEOL JSM-6480) and EDS techniques were used in the analysis of sample morphology and its chemical composition, respectively.

\subsection{Corrosion measurements}

The corrosion properties of Rex 734 alloy samples with and without $\mathrm{TiO}_{2}$ sol-gel layers were determined from accelerated corrosion measurements. The measurements were carried out in Tyrode's physiological solution at a temperature of $37{ }^{\circ} \mathrm{C}$ using potentiostat/galvanostat PGSTAT 30/1 (EcoChemie Autolab). The chemical composition of used corrosion solution is presented in Table 3 .

Electrochemical measurements were carried out in a three-electrode electrolytic cell consisting of a saturated calomel electrode as reference electrode, a platinum foil as counter electrode, and a sample (the exposed area was $0.64 \mathrm{~cm}^{2}$ ) as working electrode. All potentials presented in the paper are given versus used saturated calomel electrode $\left(\mathrm{E}^{\circ}=0.236 \mathrm{~V}\right.$ vs. standard hydrogen electrode).

The corrosion solution was deareated with pure argon for $15 \mathrm{~min}$ both before and also during measurement. Accelerated corrosion measurements were carried out according to the following measurement cycle:

1. The measurement of corrosion potential $E_{c o r}$ in an open circuit (OCP);

2. The measurement of polarization resistance $R_{p}$ according to Stern-Geary's method in a scanning range $\pm 20 \mathrm{mV}$ versus $E_{c o r}$ potential with a scan rate of $0.5 \mathrm{mV} \mathrm{s}^{-1}$;

3. The measurement of potentiodynamic characteristic from $0.2 \mathrm{~V}$ below the corrosion potential (previously stabilized) towards the anodic direction with a scan rate of $1.0 \mathrm{mV} \mathrm{s}^{-1}$. When the current density reached $5 \mathrm{~mA} \mathrm{~cm}{ }^{-2}$, the potential sweep was reversed and the backward branch was registered up to the starting potential.

The number of samples used for every corrosion test was three. Results presented in this paper are averaged values.

\section{Results}

\subsection{Phase analysis of $\mathrm{TiO}_{2}$ layers}

Diffraction patterns of Rex 734 alloy samples with $\mathrm{TiO}_{2}$ layers, annealed at $200,400,600$ and $800{ }^{\circ} \mathrm{C}$, were registered by means of the GIXD method with incidence angles $\alpha: 0.25 ; 0.50 ; 1.00 ; 2.50$ and 5.00 degrees.

The diffraction patterns $(\alpha=0.25$ and $\alpha=0.50)$ of the Rex 734 alloy samples with $\mathrm{TiO}_{2}$ layers annealed at 200 and $400{ }^{\circ} \mathrm{C}$ show that the titania layer has an amorphous character. Annealing at higher temperatures, i.e. 600 and 


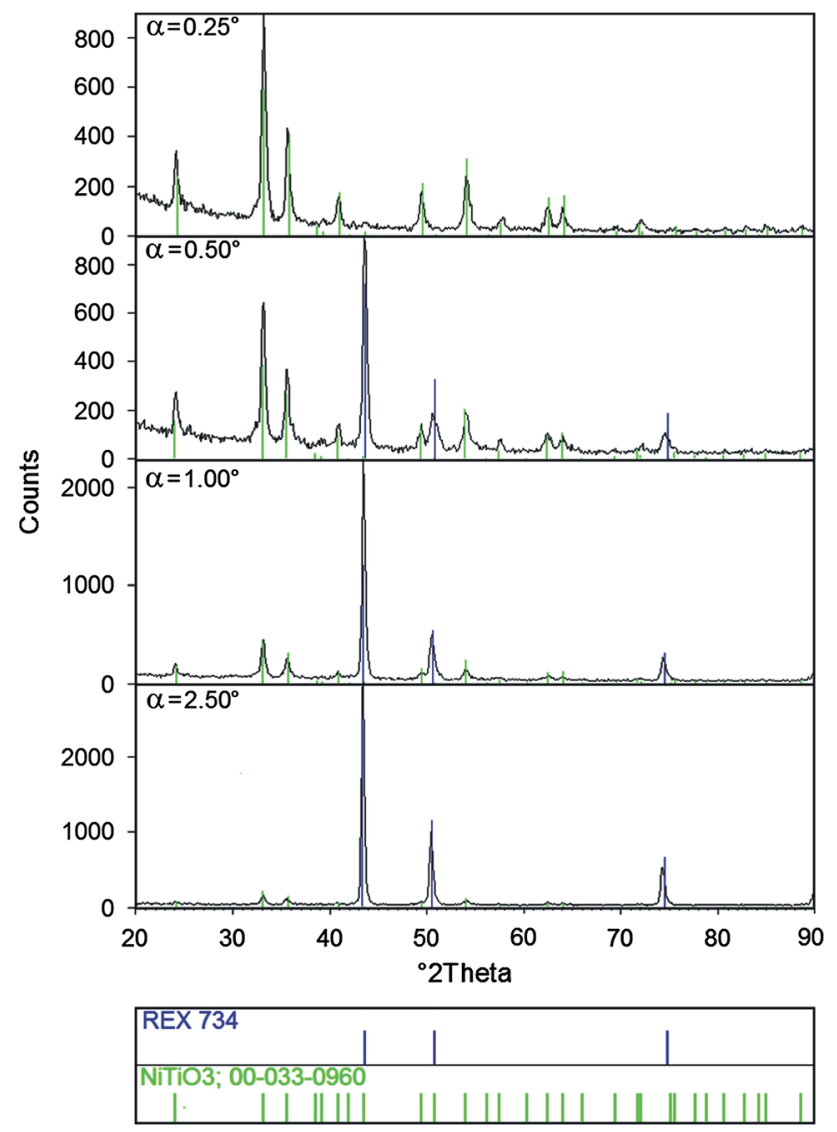

Fig. 1 Diffraction pattern and phase analysis of Rex 734 alloy sample with $\mathrm{TiO}_{2}$ layer annealed at $600{ }^{\circ} \mathrm{C}$

$800{ }^{\circ} \mathrm{C}$, results in the crystallization of the layer and the formation of new $\mathrm{TiO}_{2}$-based phases because of diffusion of the substrate elements. Qualitative phase analysis of samples with $\mathrm{TiO}_{2}$ annealed at $600{ }^{\circ} \mathrm{C}$ shows that the layer is composed of $\mathrm{NiTiO}_{3}$ (ICDD PDF 33-0960) phase (Fig. 1). In the case of samples annealed at $800{ }^{\circ} \mathrm{C}, \mathrm{NiTiO}_{3}$ (ICDD PDF 33-0960) and $\mathrm{Fe}_{2} \mathrm{TiO}_{4}$ (ICDD PDF 34-0177) phases are observed (Fig. 2). Moreover, in the case of annealing at the last temperature, a $\mathrm{Fe}_{2} \mathrm{O}_{3}$ (ICDD PDF 85-0987) phase can also be detected. Difficulties in matching $\mathrm{Fe}_{2} \mathrm{O}_{3}$ phase are the result of strong overlapping of the diffraction lines from $\mathrm{NiTiO}_{3}$ and $\mathrm{Fe}_{2} \mathrm{O}_{3}$ phases. Catalog positions of $2 \theta$ for the both phases $\left(\mathrm{NiTiO}_{3}\right.$ and $\mathrm{Fe}_{2} \mathrm{O}_{3}$ ) overlap and the only reflection that could be matched to the $\mathrm{Fe}_{2} \mathrm{O}_{3}$ phase is the one at $2 \theta$ of 39.42 . The identification of the iron oxide is in accordance with the chemical EDS analysis of the big, "protruding", porous grains containing oxide and iron (Table 8). It should be noted that the $\mathrm{Fe}_{2} \mathrm{TiO}_{4}$ phase emerges when the incidence angle is $\alpha=0.50^{\circ}$ and that the greater the incidence angle $\alpha$, the more intense the diffraction lines and there is also a simultaneous decrease in the intensity of reflections from the $\mathrm{NiTiO}_{3}$ phase. These changes confirm that only $\mathrm{NiTiO}_{3}$
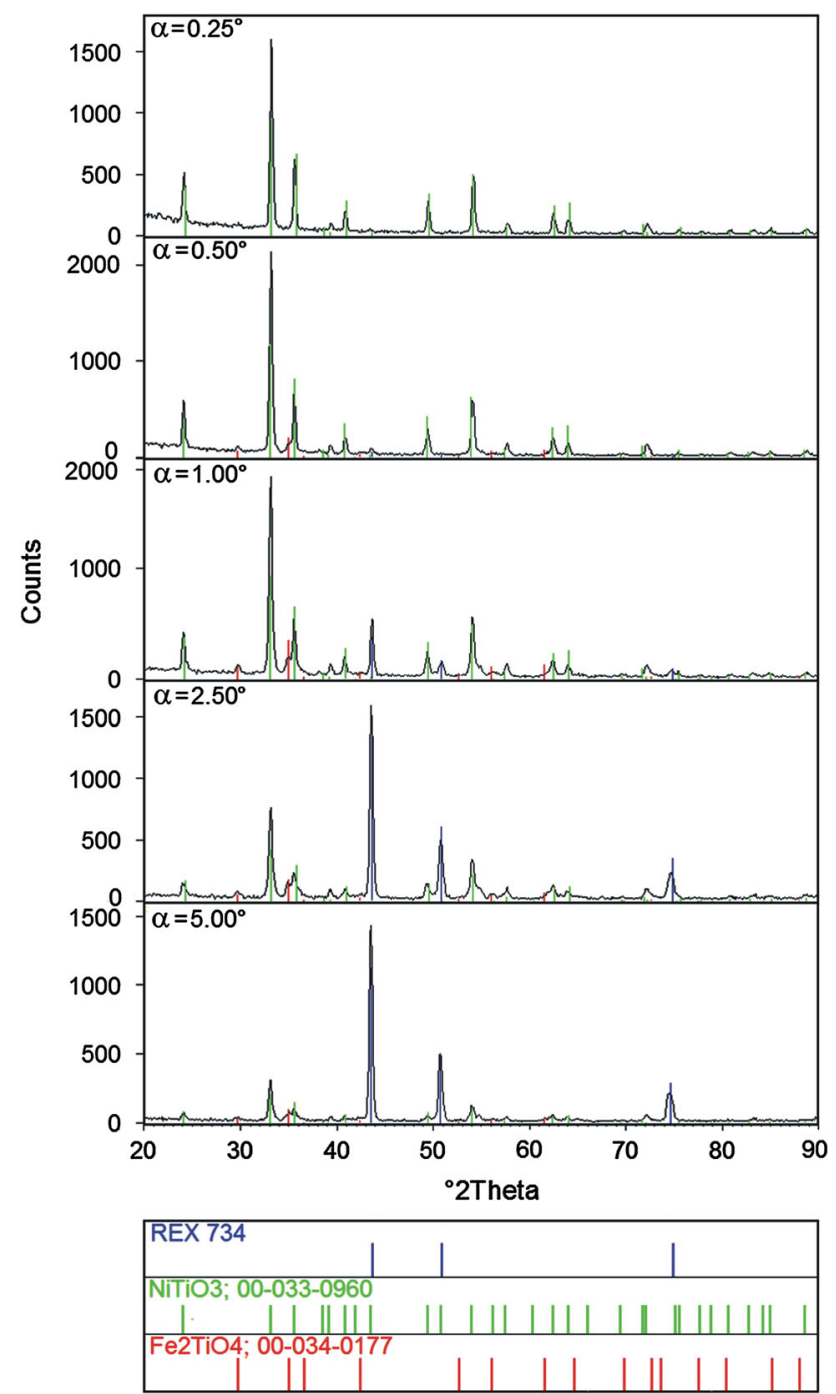

Fig. 2 Diffraction pattern and phase analysis of the Rex 734 alloy sample with $\mathrm{TiO}_{2}$ layer annealed at $800{ }^{\circ} \mathrm{C}$

is present on the surface of the layer. Furthermore, there is a continuous change of the phase content inside. Reflections that come from the Rex 734 substrate are visible for all samples.

\subsection{Thickness and density of $\mathrm{TiO}_{2}$ layers}

The thickness and density $\rho$ of the deposited $\mathrm{TiO}_{2}$ layers were determined using the reflectometry technique with the WinGix program. The reflectometric curves obtained for the Rex 734 alloy with $\mathrm{TiO}_{2}$ layers annealed at 200, 400, 600 and $800{ }^{\circ} \mathrm{C}$, have different shapes (Fig. 3), which indicates the differences in the layer's construction for individual samples.

Classic reflectometric curves were obtained only for Rex 734 samples with $\mathrm{TiO}_{2}$ layers annealed at 200 and $400{ }^{\circ} \mathrm{C}$. Therefore, it was possible to determine the value of the 


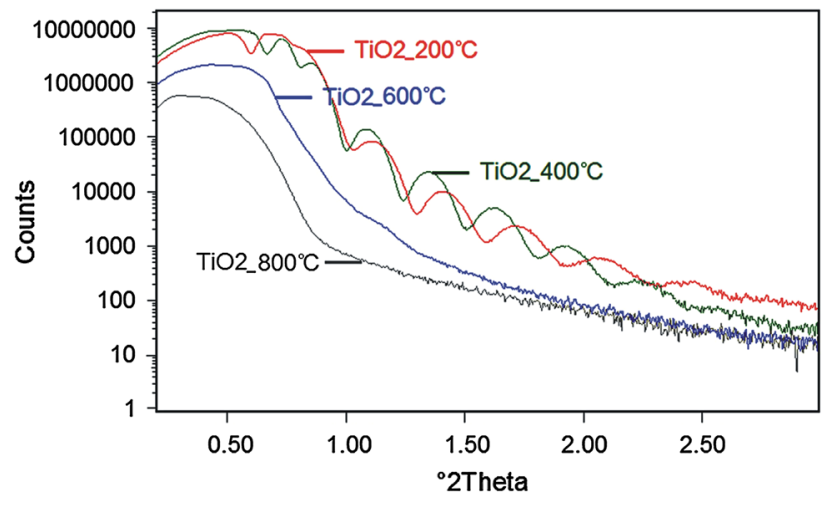

Fig. 3 Reflectometric curves collected for Rex 734 alloy with $\mathrm{TiO}_{2}$ layers annealed at: 200, 400, 600 and $800{ }^{\circ} \mathrm{C}$

Table 4 Values of density and thickness of $\mathrm{TiO}_{2}$ layers determined from reflectometric curves

\begin{tabular}{lllll}
\hline & $200{ }^{\circ} \mathrm{C}$ & $400{ }^{\circ} \mathrm{C}$ & $600{ }^{\circ} \mathrm{C}$ & $800{ }^{\circ} \mathrm{C}$ \\
\hline Thickness $(\AA)$ & 266 & 295 & - & - \\
$\rho\left(\mathrm{g} \mathrm{cm}^{-3}\right)$ & 3.91 & 4.43 & 5.07 & 4.67 \\
\hline
\end{tabular}

critical $\gamma$ angle for these samples. The thickness of these layers determined on the basis of the fluctuation intensity equals $266 \AA$ for $200{ }^{\circ} \mathrm{C}$ and $295 \AA$ for $400{ }^{\circ} \mathrm{C}$. In the case of samples with $\mathrm{TiO}_{2}$ annealed at 600 and $800{ }^{\circ} \mathrm{C}$ the reflectometric curves obtained are typical for layers of infinite thickness.

The value of the density of $\mathrm{TiO}_{2}$ layers annealed at $200{ }^{\circ} \mathrm{C}$ $\left(\rho=3.91 \mathrm{~g} \mathrm{~cm}^{-3}\right.$ ) confirms that the amorphous layer contains titania in the form of anatase $\left(\rho=3.89 \mathrm{~g} \mathrm{~cm}^{-3}\right)$. The higher density of the $\mathrm{TiO}_{2}$ layer annealed at $400{ }^{\circ} \mathrm{C}$ $\left(\rho=4.43 \mathrm{~g} \mathrm{~cm}^{-3}\right)$ may indicate the intensification of the crystallization process. Annealing of the samples at $600{ }^{\circ} \mathrm{C}$ causes subsequent densification of the $\mathrm{TiO}_{2}$ layer $\left(\rho=5.07 \mathrm{~g} \mathrm{~cm}^{-3}\right)$. Such a density value is in close correspondence with the catalog density of the $\mathrm{NiTiO}_{3}$ phase $\left(\rho=5.10 \mathrm{~g} \mathrm{~cm}^{-3}\right)$. In the case of the layer annealed at $800{ }^{\circ} \mathrm{C}$, a decrease in density to $\rho=4.67 \mathrm{~g} \mathrm{~cm}^{-3}$ is observed. The lower density value may be the result of the vacancies formation and the additional $\mathrm{Fe}_{2} \mathrm{TiO}_{4}$ phase ( $\rho=4.78 \mathrm{~g} \mathrm{~cm}^{-3}$ ) on the basis of diffusion of alloying elements to the $\mathrm{TiO}_{2}$ coating.

The values obtained for thickness and density of $\mathrm{TiO}_{2}$ layers are collected in Table 4.

\subsection{Corrosion potential}

In order to determine the corrosion potential value $E_{c o r}$ for each sample in Tyrode's solution, the potential-time dependence in relation to a reference electrode was recorded. A stable potential value was reached typically after about 2,000 s. Obtained corrosion potential values are
Table 5 Values of corrosion potential $E_{c o r}$ and shift of this potential $\Delta E_{c o r}$ for Rex 734 alloy with $\mathrm{TiO}_{2}$ layers in Tyrode's solution

\begin{tabular}{lrl}
\hline Sample & \multicolumn{1}{c}{$E_{\text {cor }}(\mathrm{V})$} & $\Delta E_{\text {cor }}(\mathrm{V})$ \\
\hline Uncoated & $-0.283 \pm 0.003$ & 0.000 \\
$+\mathrm{TiO}_{2} 200$ & $-0.054 \pm 0.083$ & 0.229 \\
$+\mathrm{TiO}_{2} 300$ & $0.000 \pm 0.035$ & 0.283 \\
$+\mathrm{TiO}_{2} 400$ & $0.014 \pm 0.028$ & 0.297 \\
$+\mathrm{TiO}_{2} 450$ & $0.121 \pm 0.029$ & 0.404 \\
$+\mathrm{TiO}_{2} 500$ & $0.118 \pm 0.029$ & 0.401 \\
$+\mathrm{TiO}_{2} 600$ & $0.035 \pm 0.110$ & 0.318 \\
$+\mathrm{TiO}_{2} 800$ & $0.080 \pm 0.044$ & 0.363 \\
\hline
\end{tabular}

presented in Table 5 with a calculated standard deviation. This table also contains the shift of corrosion potential $\Delta E_{c o r}$, as defined by the formula (3):

$\Delta E_{\text {cor }}=E_{\text {corTiO }}-E_{\text {cor } 0}$

where $E_{c o r} 0$ - corrosion potential of an uncoated sample, $E_{\text {corTiO }}$ - corrosion potential of a sample with $\mathrm{TiO}_{2}$ layers.

Analyzing the values of $E_{c o r}$ and $\Delta E_{c o r}$, it can be seen that the $\mathrm{TiO}_{2}$ layer formed on the Rex 734 alloy surface and annealed at any of the tested temperatures causes an increase in the value of the corrosion potential. This influence depends on the annealing temperature. The smallest increase in the corrosion potential is observed for samples with a layer annealed at $200{ }^{\circ} \mathrm{C}$, and the highest for samples with a layer annealed at temperatures of 450 and $500{ }^{\circ} \mathrm{C}$. For other annealing temperatures, the shift of corrosion potential has intermediate values. Extremely high value for the standard deviation of corrosion potential is observed for samples with $\mathrm{TiO}_{2}$ layer annealed at $600{ }^{\circ} \mathrm{C}$. This fact indicates that the surface properties obtained with such modification of the alloy are not repeatable.

\subsection{Polarization resistance, corrosion current and corrosion rate}

The values of polarization resistance $R_{p}$ and corrosion current $i_{c o r}$ were calculated from the slope of the SternGeary's characteristics using CorrView software (Scribner Associates Inc.). Using the determined values of polarization resistance, porosity $p$, which is associated with the formation of the $\mathrm{TiO}_{2}$ layer, was calculated and this is defined by the following equation $[34,35]$ :

$p=\frac{R_{0}}{R_{T_{i O}}}$

where $R_{0}$-polarization resistance of uncoated Rex 734 alloy, $R_{\mathrm{TiO}_{2}}$ - polarization resistance of this alloy with $\mathrm{TiO}_{2}$ layers.

$C R$ was calculated according to the standard ASTM G 102-89 [36] from the formula: 
Table 6 Values of polarization resistance $R_{p}$, porosity $p$, corrosion current $i_{c o r}$ and corrosion rate $C R$ for $\mathrm{Rex}_{734}$ alloy with $\mathrm{TiO} \mathrm{O}_{2}$ layers in Tyrode's solution

\begin{tabular}{lllll}
\hline Sample & $\left.R_{p}(\mathrm{ohm} \mathrm{cm})^{2}\right)$ & $p$ & $i_{\text {cor }}\left(\mathrm{A} \mathrm{cm}^{-2}\right)$ & $C R(\mathrm{~mm} \mathrm{year})$ \\
\hline Uncoated & $(2.67 \pm 0.19) \times 10^{5}$ & 1.000 & $(9.81 \pm 0.70) \times 10^{-8}$ & $(7.87 \pm 0.57) \times 10^{-4}$ \\
$+\mathrm{TiO}_{2} 200$ & $(5.60 \pm 2.20) \times 10^{6}$ & 0.048 & $(7.05 \pm 2.70) \times 10^{-9}$ & $(5.66 \pm 2.17) \times 10^{-5}$ \\
$+\mathrm{TiO}_{2} 300$ & $(8.26 \pm 1.04) \times 10^{6}$ & 0.032 & $(3.25 \pm 0.48) \times 10^{-9}$ & $(2.61 \pm 0.38) \times 10^{-5}$ \\
$+\mathrm{TiO}_{2} 400$ & $(9.30 \pm 0.56) \times 10^{6}$ & 0.029 & $(2.84 \pm 0.17) \times 10^{-9}$ & $(2.28 \pm 0.14) \times 10^{-5}$ \\
$+\mathrm{TiO}_{2} 450$ & $(1.28 \pm 0.18) \times 10^{7}$ & 0.021 & $(2.07 \pm 0.30) \times 10^{-9}$ & $(1.66 \pm 0.24) \times 10^{-5}$ \\
$+\mathrm{TiO}_{2} 500$ & $(7.31 \pm 1.28) \times 10^{6}$ & 0.037 & $(3.65 \pm 0.63) \times 10^{-9}$ & $(2.93 \pm 0.50) \times 10^{-5}$ \\
$+\mathrm{TiO}_{2} 600$ & $(2.50 \pm 1.47) \times 10^{6}$ & 0.107 & $(1.72 \pm 1.34) \times 10^{-8}$ & $(1.38 \pm 1.08) \times 10^{-4}$ \\
$+\mathrm{TiO}_{2} 800$ & $(4.19 \pm 0.66) \times 10^{6}$ & 0.064 & $(6.48 \pm 1.17) \times 10^{-9}$ & $(5.20 \pm 0.94) \times 10^{-5}$ \\
\hline
\end{tabular}

$C R=K_{1} \frac{i_{c o r}}{\rho} E W$

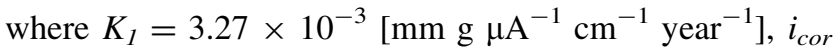
$\left[\mu \mathrm{A} \mathrm{cm}{ }^{-2}\right]$-corrosion current; $\rho\left[\mathrm{g} \mathrm{cm}^{-3}\right]$-density of alloy. The unit of the $C R$ is mm year ${ }^{-1}$.

To calculate the $C R$ value, it was assumed that in corrosion potential $E_{c o r}$ only the substrate, Rex 734 alloy, corrodes. No other corrosion processes associated with the formed and annealed $\mathrm{TiO}_{2}$ coatings were taken into account in this calculation.

$E W$ occurring in the formula for the $C R$ is an equivalent weight, which for the alloy was calculated from the following dependence [36]:

$E W=\frac{1}{\sum \frac{n_{i} f_{i}}{W_{i}}}$

where $f_{i}$ is the mass fraction of the $i$ th element in the alloy, $W_{i}$ is the atomic weight of the $i$ th element in the alloy, $n_{i}$ is the valence of $i$ th element of the alloy. According to the ASTM standard [36], only elements above one mass percent in the alloy are included in this calculation. The value of equivalent weight $E W$ for the Rex 734 alloy calculated from the above formula equals 19.14.

The determined values for $R_{p}, p, i_{c o r}$ and $C R$ with standard deviations are listed in Table 6.

As in the case of the corrosion potential, modification of the alloy surface by $\mathrm{TiO}_{2}$ layers always increases the polarization resistance. For each annealing temperature, this increase in the $R_{p}$ value is different: the highest polarization resistance values are shown by samples with a $\mathrm{TiO}_{2}$ layer annealed at a temperature of $450{ }^{\circ} \mathrm{C}$, while the lowest values are identified in samples with a layer annealed at $600{ }^{\circ} \mathrm{C}$. In relation to the polarization resistance of uncoated Rex 734 alloy, these values are about 48 times and about 9.4 times higher, respectively. As the corrosion current $i_{\text {cor }}$ and the $C R$ are inversely proportional to the polarization resistance $R_{p}$, so the changes in $R_{p}$ values are transferred onto the changes in $i_{\text {cor }}$ and $C R$

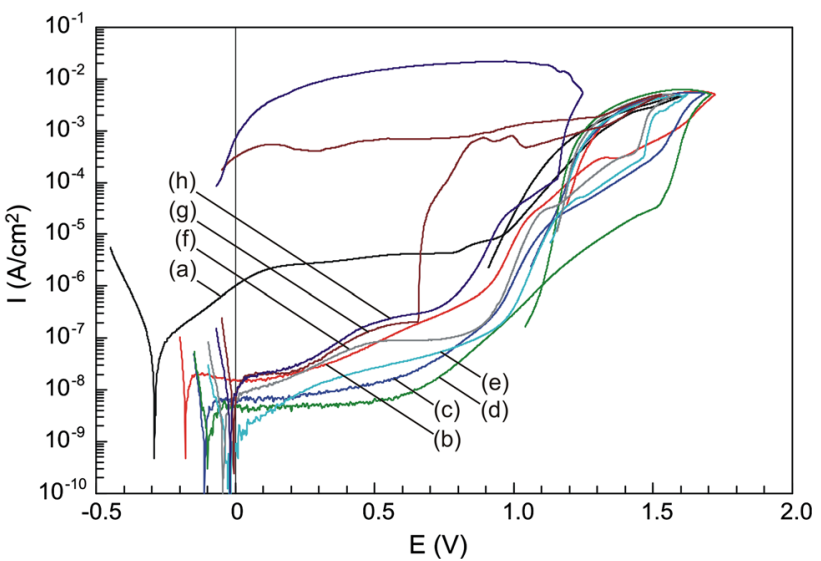

Fig. 4 Potentiodynamic characteristics for uncoated Rex 734 alloy (a) and for this alloy with $\mathrm{TiO}_{2}$ layers annealed at: $200{ }^{\circ} \mathrm{C}(b), 300{ }^{\circ} \mathrm{C}$ $(c), 400{ }^{\circ} \mathrm{C}(d), 450{ }^{\circ} \mathrm{C}(e), 500{ }^{\circ} \mathrm{C}(f), 600{ }^{\circ} \mathrm{C}(g), 800{ }^{\circ} \mathrm{C}(h)$

values. Surface modification with $\mathrm{TiO}_{2}$ layers causes a corresponding decrease in the values of both mentioned quantities.

\subsection{Potentiodynamic characteristics in the anodic polarization range}

Example potentiodynamic characteristics collected for the Rex 734 alloy (both uncoated and also samples coated with $\mathrm{TiO}_{2}$ layers) in Tyrode's solution are shown in Fig. 4. For greater clarity of the graph, fragments of the return characteristics branches have been truncated.

The shape of potentiodynamic characteristics for all tested samples is typical for localized corrosion. Some corrosion parameters have been determined from characteristics presented in Fig. 4 . The values of breakdown $E_{b}$ and repassivation $E_{\text {rep }}$ potentials and the values of current density $i_{0.6}$ determined at an arbitrarily chosen polarization potential $E=0.6 \mathrm{~V}$ [37] are collected in Table 7 .

Analyzing the results, it can be concluded that applying a $\mathrm{TiO}_{2}$ sol-gel layer significantly reduces the current density in the passive range. The greatest changes in the 
Table 7 Selected corrosion parameters as a function of annealing temperature of $\mathrm{TiO}_{2}$ layers

\begin{tabular}{lccl}
\hline Sample & $i_{0.6}(\mathrm{~A} \mathrm{~cm}$ & \\
\hline Uncoated & $4.14 \times 10^{-6}$ & $E_{b}(\mathrm{~V})$ & $E_{\text {rep }}(\mathrm{V})$ \\
$+\mathrm{TiO}_{2} 200$ & $1.42 \times 10^{-7}$ & $\sim 1.38$ & 0.96 \\
$+\mathrm{TiO}_{2} 300$ & $1.85 \times 10^{-8}$ & 1.53 & 1.22 \\
$+\mathrm{TiO}_{2} 400$ & $8.00 \times 10^{-9}$ & 1.52 & 1.14 \\
$+\mathrm{TiO}_{2} 450$ & $3.51 \times 10^{-8}$ & 1.47 & 1.17 \\
$+\mathrm{TiO}_{2} 500$ & $9.06 \times 10^{-8}$ & 1.44 & 1.18 \\
$+\mathrm{TiO}_{2} 600$ & $1.96 \times 10^{-7}$ & 0.66 & - \\
$+\mathrm{TiO}_{2} 800$ & $2.71 \times 10^{-7}$ & 1.16 & - \\
\hline
\end{tabular}

current density at a potential of $E=0.6 \mathrm{~V}$ are observed for the Rex 734 alloy with layers annealed in a temperature range of $300-450{ }^{\circ} \mathrm{C}$ - the values of $i_{0.6}$ for these samples are ca. 100-500 times lower in relation to uncoated samples. Data in Table 7 show that $\mathrm{TiO}_{2}$ layers cause changes in the values of breakdown potential. Potentials $E_{b}$ for uncoated samples and samples with $\mathrm{TiO}_{2}$ layer annealed at $200{ }^{\circ} \mathrm{C}$ could only be estimated, since there is no sharp increase in current values typical for breakdown processes. For other samples, potential $E_{b}$ is uniquely determined. The highest values of potential $E_{b}$, ca. $1.5 \mathrm{~V}$ are met in samples with $\mathrm{TiO}_{2}$ layers obtained at temperatures in the range of $300-450{ }^{\circ} \mathrm{C}$. However, the lowest value of $E_{b}$, lower than the uncoated samples, is to be found for samples with a $\mathrm{TiO}_{2}$ layer annealed at $600{ }^{\circ} \mathrm{C}$. It is worth noting that in the case of these samples and samples with a $\mathrm{TiO}_{2}$ layer annealed at $800{ }^{\circ} \mathrm{C}$, backward branches of potentiodynamic characteristics do not intersect the forward branches. This fact indicates the development of pits formed in the applied potential range. Potentiodynamic characteristics for other Rex 734 alloy samples have a current hysteresis loop associated with repassivation of pits; therefore, the repassivation potential $E_{\text {rep }}$ could be determined. This $E_{\text {rep }}$ potential is relatively low for an uncoated alloy. Higher values of $E_{\text {rep }}$ are seen in samples with $\mathrm{TiO}_{2}$ layers annealed at temperatures in the range of $200-500{ }^{\circ} \mathrm{C}$.

\subsection{Morphology of $\mathrm{TiO}_{2}$ layers}

Surface morphologies of samples with $\mathrm{TiO}_{2}$ layers annealed at 200, 400, 600 and $800{ }^{\circ} \mathrm{C}$ are shown in Fig. 5 . Morphologies marked with (a) refer to the state before corrosion, while those marked with (b) are related to the state after anodic polarization.

SEM analysis of surfaces before anodic polarization shows that randomly located irregularly shaped precipitates occur on the homogeneous surface of samples annealed at 200 and $400{ }^{\circ} \mathrm{C}$. These precipitates have a higher level of $\mathrm{Nb}$, Mo and $\mathrm{Cr}$. Nb levels reach 42 at.\% (58 wt\%), Mo
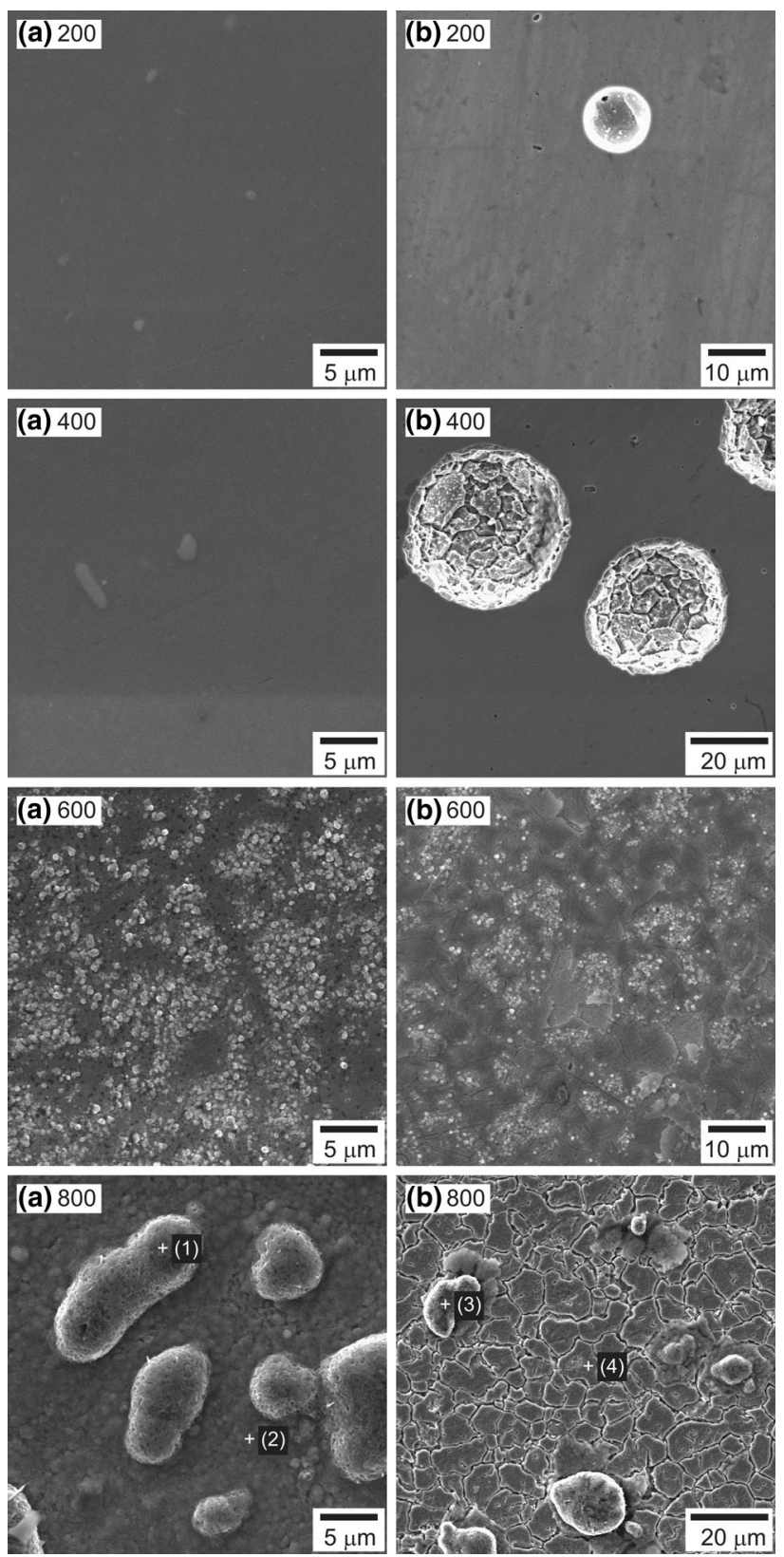

Fig. 5 SEM images of the samples with $\mathrm{TiO}_{2}$ layers annealed at 200, 400,600 and $800{ }^{\circ} \mathrm{C}$; $\mathbf{a}$ as prepared (before corrosion), b after anodic polarization in Tyrode's solution

content is ca. 7.7 at. $\%$ (11 wt\%), and $\mathrm{Cr}$ is ca. 25 at.\% (19 wt\%). The result of anodic polarization is evident local pitting corrosion manifested by creation of circular pits, stochastically distributed on the surface of samples. SEM analysis conducted after anodic polarization does not show the above mentioned precipitates on the sample surfacesthe elemental composition inside and outside the pits is similar to the original elemental composition of the investigated alloy.

Surface morphology analysis of the samples, annealed at $600{ }^{\circ} \mathrm{C}$, shows fine-grained crystallites. They are often laid 
out as "islands", which reflects the microstructure of the Rex 734 substrate. Similar sample surface morphology is observed after annealing at $800{ }^{\circ} \mathrm{C}$. Big "protruding" porous grains are visible on the surface with fine-grained, homogeneously distributed, globular crystallites. Results of EDS analysis (Table 8) show that these grains have higher levels of $\mathrm{O}$ and $\mathrm{Fe}$.

In the case of samples with $\mathrm{TiO}_{2}$ layers annealed at temperatures of 600 and $800{ }^{\circ} \mathrm{C}$, anodic polarization causes local corrosion damage by partial removal of the $\mathrm{TiO}_{2}$ layer and revealing of the microstructure of the substrate. In the case of samples annealed at $600{ }^{\circ} \mathrm{C}$, this damage was less extensive than in the case of samples heat treated at $800{ }^{\circ} \mathrm{C}$. SEM analysis of samples with $\mathrm{TiO}_{2}$ layer annealed at $800{ }^{\circ} \mathrm{C}$ shows an additional occurrence of intergranular corrosion effects in the area without the layer. The results of EDS analysis show that the elemental composition of this area is similar to the original elemental composition of the investigated alloy. SEM-EDS analysis also indicates that porous grains with higher levels of $\mathrm{Fe}$ and $\mathrm{O}$ are still present on the surface, even after anodic polarization.

\section{Discussion}

Considering the results of phase analysis, and the thickness and density of investigated $\mathrm{TiO}_{2}$ layers, it was possible to describe the type of layer-substrate connection, as well as the structure of the coating, formed at different temperatures.

On the basis of the phase analysis, it was stated that layers formed at 200 and $400{ }^{\circ} \mathrm{C}$ had an amorphous structure. Simultaneously, the density values of these layers indicated that crystal forms of titania were also present. The determined density value of the $\mathrm{TiO}_{2}$ layer annealed at $200{ }^{\circ} \mathrm{C}$ was close to the density value of anatase. This could be explained by the formation of anatase microcrystals in the amorphous structure of titania. Analogous mixed structures have also been reported in literature concerning research into $\mathrm{TiO}_{2}$ layers on $\mathrm{Ti}$ [38-41]. Increasing the annealing temperature up to $400{ }^{\circ} \mathrm{C}$ caused the formation of a thicker and much denser layer than the layer created at a lower temperature. At both described annealing temperatures, the interaction between substrate and deposited $\mathrm{TiO}_{2}$ layers probably had an adhesive character.

Phase analyses of $\mathrm{TiO}_{2}$ layers formed at 600 and $800{ }^{\circ} \mathrm{C}$ showed the diffusion process occurring on the interface of the $\mathrm{TiO}_{2}$ layer and the Rex 734 substrate. As a result, new phases were formed on the basis of $\mathrm{TiO}_{2}$ and alloying elements. Based on phase analysis and density measurements, it could be stated that samples annealed at $600{ }^{\circ} \mathrm{C}$ were covered by the $\mathrm{NiTiO}_{3}$ phase rather than pure $\mathrm{TiO}_{2}$. This $\mathrm{NiTiO}_{3}$ phase appeared on the surface as a result of $\mathrm{Ni}$ diffusion from the alloy to the $\mathrm{TiO}_{2}$ layer. Analogous measurements for samples annealed at $800{ }^{\circ} \mathrm{C}$ showed that coatings formed onto these samples are double layered. The inner layer consisted of a $\mathrm{Fe}_{2} \mathrm{TiO}_{4}$ phase, while the outer layer was an $\mathrm{NiTiO}_{3}$ phase. Moreover, a few crystallized, porous grains of $\mathrm{Fe}_{2} \mathrm{O}_{3}$ phase could be observed on the surface. They were also detected in SEM investigations. At both described annealing temperatures, the interaction between substrate and deposited $\mathrm{TiO}_{2}$ layers had a diffusive character.

Analyzing the impact of $\mathrm{TiO}_{2}$ layers on the corrosion properties of Rex 734 alloy, it should be concluded that these layers annealed at all the temperatures used improved the corrosion resistance of this alloy. The effect of a shifted corrosion potential towards more anodic values, the increase in polarization resistance, reduced porosity, corrosion current and $C R$ can be explained by the protective properties of $\mathrm{TiO}_{2}$ coating. This protective effect is also evident in the whole passive range for all samples.

An analysis of the potentiodynamic characteristics shows that $\mathrm{TiO}_{2}$ layers annealed at $400{ }^{\circ} \mathrm{C}$ give the greatest improvement in these properties. The layers annealed at this temperature and at a temperature of $200{ }^{\circ} \mathrm{C}$, both adhesively bound to the substrate, considerably reduce the $\mathrm{CR}$ by blocking the transport of metallic ions. Pitting corrosion occurring as a result of anodic polarization of the alloy coated with layers annealed at these temperatures may be associated with those precipitates with higher levels of $\mathrm{Nb}$, Mo and $\mathrm{Cr}$, which were detected on the alloy surface. Around these precipitates, the alloy substrate is deficient in $\mathrm{Nb}$, Mo and $\mathrm{Cr}$ elements. Therefore, these sites may be susceptible to corrosive attack. It should be noted that the composition of precipitates, given in Sect. 3.6, may be affected by a significant error that results from the small size of these precipitates. A similar problem with the interference of the surrounding matrix was signalled by Pan et al. [42]. He reported that EDX analysis showed that Z-phase precipitations contain ca. $27 \% \mathrm{Cr}$ and ca. $6 \%$ Mo, while typical levels of these elements in the substrate amount to 22 and $3 \%$, respectively. The composition of the Z-phase precipitates and the mechanism of their formation is described extensively in the literature [1, 43-48]. Pitting corrosion occurs at locations corresponding to these precipitates [42, 43].

The weakest protective properties are exhibited by $\mathrm{TiO}_{2}$ layers annealed at the temperatures of 600 and $800{ }^{\circ} \mathrm{C}$. The main reason for this may be the diffuse nature of the bond between the substrate and the coating. Changes in the chemical composition of $\mathrm{TiO}_{2}$ coating due to diffusion of $\mathrm{Ni}$ and $\mathrm{Fe}$ to the coating, as found in the phase analysis, 
Table 8 Chemical composition of grains crystallized on the samples annealed at $800{ }^{\circ} \mathrm{C}$

\begin{tabular}{|c|c|c|c|c|c|c|c|c|}
\hline \multirow{3}{*}{ Element } & \multicolumn{4}{|c|}{ As prepared (before corrosion) } & \multicolumn{4}{|c|}{ After anodic polarization } \\
\hline & \multicolumn{2}{|l|}{ Point (1) } & \multicolumn{2}{|c|}{ Point (2) } & \multicolumn{2}{|c|}{ Point (3) } & \multicolumn{2}{|c|}{ Point (4) } \\
\hline & at. $\%$ & $\mathrm{wt} \%$ & at. $\%$ & $\mathrm{wt} \%$ & at. $\%$ & wt $\%$ & at. $\%$ & $\mathrm{wt} \%$ \\
\hline $\mathrm{O}$ & 62.618 & 32.531 & 56.990 & 27.266 & 64.847 & 34.672 & 10.578 & 3.281 \\
\hline $\mathrm{Si}$ & 0.059 & 0.054 & 0.319 & 0.268 & 0.143 & 0.135 & 0.911 & 0.496 \\
\hline $\mathrm{Ti}$ & 0.132 & 0.204 & 0.440 & 0.629 & 0.097 & 0.155 & 0.192 & 0.178 \\
\hline $\mathrm{Cr}$ & 3.760 & 6.348 & 11.043 & 17.170 & 2.258 & 3.924 & 20.083 & 20.245 \\
\hline $\mathrm{Mn}$ & 3.533 & 6.302 & 1.936 & 3.180 & 2.037 & 3.740 & 3.558 & 3.790 \\
\hline $\mathrm{Fe}$ & 28.163 & 51.068 & 23.121 & 38.611 & 30.215 & 56.389 & 54.883 & 59.423 \\
\hline $\mathrm{Ni}$ & 1.570 & 2.991 & 4.223 & 7.412 & 0.238 & 0.467 & 7.789 & 8.864 \\
\hline $\mathrm{Nb}$ & 0.166 & 0.501 & 0.759 & 2.109 & 0.084 & 0.261 & 0.139 & 0.251 \\
\hline Mo & 0.000 & 0.000 & 1.169 & 3.355 & 0.080 & 0.257 & 1.867 & 3.472 \\
\hline
\end{tabular}

reveal an increase in the corrosion current and a low value of breakdown potential. Rex 734 alloy heat treated at these temperatures does not have the ability to repassivate pits once formed. Evans et al. [26] and Zhu et al. [27] discussed the adverse effect of diffusion layer thus formed, but mainly in terms of photocatalytic properties. Zhu et al. [27] identified diffusion of $\mathrm{Fe}$ and forming of an $\mathrm{Fe}_{2} \mathrm{O}_{3}$ interlayer and rhombohedral $\mathrm{Fe}_{2} \mathrm{O}_{3}$ species on SS 304 steel. The analogical formation of the diffusion layer and the diffusion of alloying elements of the investigated Rex 734 into the $\mathrm{TiO}_{2}$ film, both at 600 and $800{ }^{\circ} \mathrm{C}$, are certain to have a crucial influence on the corrosion protective properties of $\mathrm{TiO}_{2}$.

Robinson and Jack [46] has shown that, in Rex 734, the $\mathrm{Z}$-phase is formed as inter- and intragranular precipitates in the temperature range of $700-1,000{ }^{\circ} \mathrm{C}$. An extensive analysis of the formation of Z-phase precipitation in austenitic stainless steel at high temperatures was presented by Sourmail [47]. Thermal treatment of stainless steel at high temperatures also causes the formation of ageinginduced intergranular precipitates ( $\chi$-phase) [43]. The presence of $\chi$-phase, which normally occurs at grain boundaries, depletes the chromium content leading to intergranular corrosion [49]. The presence of such a phase has proven to be highly sensitive to alloy processing parameters such as the cooling rate after a final heat treatment. The $\chi$-phase can be avoided during production by sufficiently rapid cooling [43]; however, in our studies we used the gradual cooling of the samples in the oven, to avoid the shrinkage and cracking of the applied $\mathrm{TiO}_{2}$ layers. Under such conditions, formation of Z-phase and $\chi$ phase intermetallic precipitates is very possible. The presence of these precipitates would explain intergranular corrosion and the revealing of the microstructure of the substrate due to anodic polarization of Rex 734 alloy samples with $\mathrm{TiO}_{2}$ layer annealed at $800{ }^{\circ} \mathrm{C}$. An analogous alloy microstructure was obtained in corrosion studies in $0.5 \mathrm{M} \mathrm{H}_{2} \mathrm{SO}_{4}$ [50].

\section{Summary}

Structural analysis and corrosion tests of titanium dioxide layers deposited onto the surface of ISO 5832-9 biomedical alloy by the sol-gel method and annealed at temperatures in the range of $200-800{ }^{\circ} \mathrm{C}$ were performed in this study. The morphology, chemical composition, crystallinity, thickness and density of deposited $\mathrm{TiO}_{2}$ layers were determined using suitable electron and X-ray measurement methods. Anticorrosion properties of $\mathrm{TiO}_{2}$ layers were studied using electrochemical methods. The results may be summarized as follows:

1. The sol-gel procedure used in this study allows homogenous and crack-free $\mathrm{TiO}_{2}$ layers to be obtained on Rex 734 biomedical alloy. The character of interaction between substrate and deposited $\mathrm{TiO}_{2}$ layers depends on annealing temperature. At temperatures of 200 and $400{ }^{\circ} \mathrm{C}$, the interaction has an adhesive character, while at 600 and $800{ }^{\circ} \mathrm{C}$ it has a diffusive character.

2. The structure of $\mathrm{TiO}_{2}$ layers depends on annealing temperature. Below the temperature of $400{ }^{\circ} \mathrm{C}, \mathrm{TiO}_{2}$ layers are amorphous or amorphous with anatase crystallites. At temperatures higher than $600{ }^{\circ} \mathrm{C}$, new phases containing $\mathrm{Ti}$ and alloying elements (Ni and/or Fe) are formed.

3. All the obtained $\mathrm{TiO}_{2}$ coatings exhibit anticorrosion properties. Their protective properties are related to the crystalline structure and character of the substratelayer interaction. The best anticorrosion properties are exhibited by coatings of amorphous structure with anatase microcrystalities and an adhesive connection 
character with the substrate of the Rex 734 biomedical alloy, whereas the weakest protective properties are noted in diffusive layers, which contain new $\mathrm{TiO}_{2}-$ based phases instead of pure $\mathrm{TiO}_{2}$ crystal structures.

4. During heat treatment of the Rex 734 alloy with $\mathrm{TiO}_{2}$ coating, some precipitates are formed. These precipitates may have an impact on the type of corrosion damage created as a result of anodic polarization. At low temperatures $\left(200\right.$ and $400{ }^{\circ} \mathrm{C}$ ) pitting corrosion with circular pits occurs, while at higher temperatures $\left(600\right.$ and $800{ }^{\circ} \mathrm{C}$ ) local corrosion by partial removal of $\mathrm{TiO}_{2}$ layer is noted.

In conclusion, from the corrosion point of view the best $\mathrm{TiO}_{2}$ sol-gel coatings for stainless steel intended for biomedical applications seem to be those obtained at $400{ }^{\circ} \mathrm{C}$.

Acknowledgments This study was supported by Grant No. N N507 501339 of the National Science Centre. The authors wish to express their thanks to J. Borowski (MEDGAL, Poland) for the Rex 734 alloy.

Open Access This article is distributed under the terms of the Creative Commons Attribution License which permits any use, distribution, and reproduction in any medium, provided the original author(s) and the source are credited.

\section{References}

1. Giordani EJ, Guimaraes VA, Pinto TB, Ferreira I. Effect of precipitates on the corrosion-fatigue crack initiation of ISO 5832-9 stainless steel biomaterial. Int J Fatigue. 2004;26:1129-36.

2. Uggowitzer PJ, Magdowski R, Speidel MO. Nickel free high nitrogen austenitic steels. ISIJ Int. 1996;36:901-8.

3. Thomman UI, Uggowitzer PJ. Wear-corrosion behavior of biocompatible austenitic stainless steels. Wear. 2000;239:48-58.

4. British Stainless Steel Association. Selection of stainless steels for surgical implants. http://www.bssa.org.uk/topics.php?article= 138. Accessed 20 June 2013.

5. Liu C, Bi Q, Matthews A. EIS comparison on corrosion performance of PVD TiN and $\mathrm{CrN}$ coated mild steel in $0.5 \mathrm{~N} \mathrm{NaCl}$ aqueous solution. Corros Sci. 2001;43:1953-61.

6. Battison GA, Gerbasi R, Porchia M. Influence of substrate on structural properties of $\mathrm{TiO}_{2}$ thin films obtained via MOCVD. Thin Solid Films. 1994;239:186-91.

7. Fallet M, Mahdjoub H, Gautier B, Bauer JP. Electrochemical behavior of ceramic sol-gel coatings on mild steel. J Non-Cryst Solids. 2001;293-295:527-33.

8. Pang X, Zhitomirsky I, Niewczas M. Cathodic electrolytic deposition of zirconia films. Surf Coat Technol. 2005;195:138-46.

9. Guillard C, Beaugiraud B, Dutriez C, Herrmann JM, Jaffrezic H, Jaffrezic-Renault N, Lacroix M. Physicochemical properties and photocatalytic activities of $\mathrm{TiO}_{2}$-films prepared by sol-gel methods. Appl Catal B. 2002;39:331-42.

10. Velten D, Biehl V, Aubertin F, Valeske B, Possart W, Breme J. Preparation of $\mathrm{TiO}_{2}$ layers on cp-Ti and Ti6Al4 $\mathrm{V}$ by thermal and anodic oxidation and by sol-gel coating techniques and their characterization. J Biomed Mater Res. 2002;59:18-28.

11. Alam MJ, Cameron DC. Preparation and characterization of $\mathrm{TiO}_{2}$ thin films by sol-gel method. J Sol-Gel Sci Technol. 2002;25:137-45.
12. Galliano P, De Damborenea JJ, Pascual MJ, Duran A. Sol-gel coatings on 316L steel for clinical applications. J Sol-Gel Sci Technol. 1998;13:723-7.

13. Wang D, Bierwagen GP. Sol-gel coatings on metals for corrosion protection. Prog Org Coat. 2009;64:327-38.

14. Velten D, Eisenbarth E, Schanne N, Breme J. Biocompatible $\mathrm{Nb}_{2} \mathrm{O}_{5}$ thin films prepared by means of the sol-gel process. J Mater Sci Mater Med. 2004;15:457-61.

15. Tayade RJ, Surolia PK, Kulkarni RG, Jasra RV. Photocatalytic degradation of dyes and organic contaminants in water using nanocrystalline anatase and rutile $\mathrm{TiO}_{2}$. Sci Technol Adv Mater. 2007;8:455-62.

16. Kopac T, Bozgeyik K. Effect of surface area enhancement on the adsorption of bovine serum albumin onto titanium dioxide. Coll Surf B. 2010;76:265-71.

17. Głuszek J, Masalski J, Furman P, Nitsch K. Structural and electrochemical examinations of $\mathrm{PACVD} \mathrm{TiO}_{2}$ films in Ringer solution. Biomaterials. 1997;18:789-94.

18. Shen GX, Chen YC, Lin L, Lin CJ, Scantlebury D. Study on a hydrophobic nano- $\mathrm{TiO}_{2}$ coating and its properties for corrosion protection of metals. Electrochim Acta. 2005;50:5083-9.

19. Shen GX, Chen YC, Lin CJ. Corrosion protection of $316 \mathrm{~L}$ stainless steel by a $\mathrm{TiO}_{2}$ nanoparticle coating prepared by sol-gel method. Thin Solid Films. 2005;489:130-6.

20. Shan CX, Hou X, Choy KL. Corrosion resistance of $\mathrm{TiO}_{2}$ films grown on stainless steel by atomic layer deposition. Surf Coat Technol. 2008;202:2399-402.

21. Atik M, de Lima Neto P, Avaca LA, Aegerter MA. Sol-gel thin films for corrosion protection. Ceram Int. 1995;21:403-6.

22. Nazeri A, Trzaskoma-Paulette PP, Bauer D. Synthesis and properties of cerium and titanium oxide thin coatings for corrosion protection of 304 stainless steel. J Sol-Gel Sci Technol. 1997;10:317-31.

23. Krishna DSR, Sun Y. Thermally oxidised rutile- $\mathrm{TiO}_{2}$ coating on stainless steel for tribological properties and corrosion resistance enhancement. Appl Surf Sci. 2005;252:1107-16.

24. Balamurugan A, Kannan S, Rajeswari S. Evaluation of $\mathrm{TiO}_{2}$ coatings obtained using the sol-gel technique on surgical grade type 316L stainless steel in simulated body fluid. Mater Lett. 2005;59:3138-43.

25. Vasconcelos DCL, Nunes EHM, Sabioni ACS, da Costa JCD, Vasconcelos WL. Structural characterization and corrosion behavior of stainless steel coated with sol-gel titania. J Mater Eng Perform. 2012;21:411-7.

26. Evans P, English T, Hammond D, Pemble ME, Sheel DW. The role of $\mathrm{SiO}_{2}$ barrier layers in determining the structure and photocatalytic activity of $\mathrm{TiO}_{2}$ films deposited on stainless steel. Appl Catal A. 2007;321:140-6.

27. Zhu Y, Zhang L, Wang L, Fu Y, Cao L. The preparation and chemical structure of $\mathrm{TiO} 2$ film photocatalysts supported on stainless steel substrates via the sol-gel method. J Mater Chem. 2001;11:1864-8

28. Piwoński I. Preparation method and some tribological properties of porous titanium dioxide layers. Thin Solid Films. 2007;515: 3499-506.

29. Fritz SE, Martin SM, Frisbie CD, Ward MD, Toney MF. Structural characterization of a pentacene monolayer on an amorphous $\mathrm{SiO}_{2}$ substrate with grazing incidence X-ray diffraction. J Am Chem Soc. 2004;126(13):4084-5.

30. Dutta P. Grazing incidence X-Ray diffraction. Curr Sci. 2000;78: 1478-83.

31. Kogan V, Bethke K, Vries R. Applying X-rays in material analysis. Nucl Instrum Method A. 2003;509:290-3.

32. Stoev KN, Samurai K. Review on grazing incidence X-ray spectrometry and reflectometry. Spectrochimi Acta B. 1999;54: $41-82$. 
33. Kolbe M, Beckhoff B, Krumrey M, Ulm G. Comparison of reference-free X-ray fluorescence analysis and X-ray reflectometry for thickness determination in the nanometer range. Appl Surf Sci. 2005;252:49-52.

34. Tato W, Landolt D. Electrochemical determination of the porosity of single and duplex PVD coatings of titanium and titanium nitride on brass. J Electrochem Soc. 1998;145:4173-81.

35. Diaz B, Harkonen E, Światowska J, Maurice V, Seyeux A, Marcus P, Ritala P. Low-temperature atomic layer deposition of $\mathrm{Al}_{2} \mathrm{O}_{3}$ thin coatings for corrosion protection of steel: surface and electrochemical analysis. Corros Sci. 2011;53:2168-75.

36. ASTM G 102-89. Standard practice for calculation of corrosion rates and related information from electrochemical measurements. 2004.

37. Takemoto S, Hattori M, Yoshinari M, Kawada E, Oda Y. Corrosion behavior and surface characterization of titanium in solution containing fluoride and albumin. Biomaterials. 2005;26: 829-37.

38. Shibata T, Zhu YC. The effect of film formation conditions on the structure and composition of anodic oxide films on titanium. Corros Sci. 1995;37:253-70.

39. Sul YT, Johansson CB, Jeong Y, Albrektsson T. The electrochemical oxide growth behaviour on titanium in acid and alkaline electrolytes. Med Eng Phys. 2001;23:329-46.

40. Sul YT, Johansson CB, Petronis S, Krozer A, Jeong Y, Wennerberg A, Albrektsson T. Characteristics of the surface oxides on turned and electrochemically oxidized pure titanium implants up to dielectric breakdown: the oxide thickness, micropore configurations, surface roughness, crystal structure and chemical composition. Biomaterials. 2002;23:491-501.
41. Sul YT. The significance of the surface properties of oxidized titanium to the bone response: special emphasis on potential biochemical bonding of oxidized titanium implant. Biomaterials. 2003;24:3893-907.

42. Pan J, Karlen C, Ulfvin C. Electrochemical study of resistance to localized corrosion of stainless steels for biomaterial applications. J Electrochem Soc. 2000;147:1021-5.

43. Ornhagen C, Nilsson JO, Vannevik H. Characterization of a nitrogen-rich austenitic stainless steel used for osteosynthesis devices. J Biomed Mater Res. 1996;31:97-103.

44. Antunes RA, de Oliveira MCL. Corrosion fatigue of biomedical metallic alloys: mechanisms and mitigation. Acta Biomater. 2012;8:937-62.

45. Erneman J, Schwind M, Liu P, Nilsson J-O, Andren H-O, Agren J. Precipitation reactions caused by nitrogen uptake during service at high temperatures of a niobium stabilised austenitic stainless steel. Acta Mater. 2004;52:4337-50.

46. Robinson EW, Jack DH. Precipitation of Z-phase in a highnitrogen stainless steel. J Heat Treat. 1985;4:69-74.

47. Sourmail T. Precipitation in creep resistant austenitic stainless steels. Mater Sci Technol. 2001;17:1-14.

48. Giordani EJ, Jorge AM Jr, Balancin O. Proportion of recovery and recrystallization during interpass times at high temperatures on a $\mathrm{Nb}$ - and N-bearing austenitic stainless steel biomaterial. Scr Mater. 2006;55:743-6.

49. Xu W, San Martin D, Rivera-Díaz-del-Castillo PEJ, van der Zwaag S. Modelling chi-phase precipitation in high molybdenum stainless steels. Adv Mat Res. 2006;15-17:531-6.

50. Burnat B. Investigation of electrochemical corrosion of $\mathrm{FeCr}$ biomedical alloys. PhD Thesis. University of Lodz. 2008. 